\title{
Effects of Irrigation Regimes on Yield and Water Use by Sweetpotato
}

\author{
Doyle A. Smittle', Melvin R. Hall', and James R. Stansell ${ }^{2}$ \\ University of Georgia, Coastal Plain Experiment Station, Tifton, GA 31793 \\ Additional index words. Ipomoea batatas, soil water tension, evapotranspiration, evaporation, irrigation scheduling, \\ water use modeling
}

\begin{abstract}
Sweetpotatoes [Ipomoea batatas (L.) Lam CV. Georgia Jet] were grown on two soil types in drainage lysimeters under controlled soil water regimes during 1982 and 1983 . Water regimes consisted of irrigating the sweetpotatoes throughout growth when soil water tension at $23 \mathrm{~cm}$ exceeded 25,50 , or $100 \mathrm{kPa}$ or by allowing a 100kPa water stress before root enlargement, during early root enlargement, or throughout root enlargement. Water use and marketable yields were greater when sweetpotatoes were grown on a Tifton loamy sand (fine loamy, siliceous, thermic, Plinthitic Paleudult) than when grown on a Bonifay sand (loamy, siliceous, thermic, Grossarenic, Plinthitic Paleudult). Water use, marketable yield, and yield of U.S. \#1 grade roots generally decreased when soil water tensions exceeded $25 \mathrm{kPa}$ before irrigation, although soil water stress of $100 \mathrm{kPa}$ during storage root development did not significantly affect yield. Regression equations are provided to describe the relationships of water use to plant age and to compute daily evapotranspiration : pan evaporation ratios (crop factors) for sweetpotatoes irrigated at 25,50 , and $100 \mathrm{kPa}$ of soil water tension.
\end{abstract}

Sweetpotatoes are considered moderately tolerant to drought conditions due to their low plant growth habit and extensive root system (Hammett et al., 1982). Yields of sweetpotatoes grown at several locations were increased by irrigation (Bowers et al., 1956; Ghuman and Lal, 1983; Hammett et al., 1982; Hernandez et al., 1965; Jones, 1961; Lambeth, 1956; Lana and Peterson, 1956); however, there is no consensus as to the optimum soil water status at which irrigation should begin. Lambeth (1956) reported that sweetpotato yields were 67\% greater when irrigated at $50 \%$ available moisture than when irrigated at 25\% available soil moisture. Lana and Peterson (1956) reported similar sweetpotato yield responses when irrigated at $50 \%$ or higher soil moisture content. In contrast, Bowers et al. (1956) reported increased yield when sweetpotatoes were irrigated at $20 \%$ and $50 \%$ available soil moisture content as compared to nonirrigated plots, but yields from the two irrigated treatments were similar. Hammett et al. (1982) and Jones (1961) also reported that yields were similar when sweetpotatoes were irrigated at soil moisture contents $>20 \%$. Excessive irrigation should be avoided because poor soil aeration may cause poor storage root induction or development (Chua and Kays, 1981).

In rainfall-excluded plots, Jones (1961) found that 51\% and $81 \%$ of the sweetpotato roots were in the top 23 and $46 \mathrm{~cm}$ of the soil, respectively. He also found that the soil moisture level at irrigation had little effect on the total amount of water required by sweetpotatoes if sufficient water was applied to bring the soil in the root zone to field capacity. However, the stage of growth had a pronounced effect on evapotranspiration. Evapotranspiration rates were $2.6,3.8$, and $2.5 \mathrm{~mm} \cdot$ day $^{-1}$ during early, middle, and late growth periods, respectively. These differences in evapotranspiration were not totally attributable to weather conditions, because potential evapotranspiration rates as calculated by Penman's equation (Penman et al., 1967) were 4.5, 4.0, and $3.4 \mathrm{~mm} \cdot \mathrm{day}^{-1}$ during early, middle, and late

\footnotetext{
Received for publication 8 Nov. 1989. Supported by state and Hatch Act funds allocated to the Georgia Agricultural Experiment Stations and grant funds from the Richard King Mellon Foundation. The cost of publishing this paper was defrayed in part by the payment of page charges. Under postal regulations, this paper therefore must be hereby marked advertisement solely to indicate this fact.

'Dept. of Horticulture.

${ }^{2}$ Dept. of Agricultural Engineering.
}

growth periods. The differences between potential and actual evapotranspiration during early and late growth stages were attributed to incomplete ground cover during early growth and to senescence and reduced efficiency of older leaves during the late growth stage. Jones (1961) stated that standard tables of evapotranspiration values could be used to predict irrigation needs for sweetpotatoes during midseason, but that corrections are required during early and late-season growth.

The relationships of sweetpotato yields and water use to soil water tensions and plant age warrant further definition. This study was conducted to determine yield and water use responses of sweetpotatoes to several irrigation regimes and to relate water use throughout growth to pan evaporation.

\section{Materials and Methods}

'Georgia Jet' sweetpotatoes were grown in lysimeters during 1982 and 1983. The lysimeter plots, containing either a Tifton loamy sand or a Bonifay sand, were equipped with automatic shelters activated by rainfall (Stansell and Smittle, 1980). A combination of between-plot moisture barriers (1.2 m deep) and subsurface drains was used to isolate the plots from each other and from groundwater intrusion. Each shelter protected 24 plots of a single soil type that each were $1.5 \times 1.8 \mathrm{~m}$ (length/width). Each plot contained six resistance block moisture sensors placed at depths of $10,23,38,53,81$, and $107 \mathrm{~cm}$. The sensors were read daily at $0800 \mathrm{HR}$ by a data collection system controlled by an on-site computer. The data were processed by the computer and a daily status report was printed that included soil water content at each sensor location and irrigation requirements for the day. Soil water data were stored for future analyses.

Irrigation treatments were arranged in a randomized complete-block design with four replications. Treatments consisted of irrigating at a soil water tension of 25,50 , or $100 \mathrm{kPa}$ throughout growth or irrigating at $25 \mathrm{kPa}$ with the implementation of a $100-\mathrm{kPa}$ water stress period before root enlargement, during early root enlargement, or throughout root enlargement. Water applications were made with a hand-held sprinkler nozzle and were based on visual observation for $\approx 2$ weeks after transplanting because roots were not sufficiently established to affect the soil water sensors. After this time, irrigation applications were scheduled by measured soil water deficits. When sensors at the 23-cm depth showed a soil water deficit corresponding to 
the treatment requirements, irrigation was applied to refill the surface $30 \mathrm{~cm}$ of the soil profile to field capacity $(8 \mathrm{kPa})$. The amount of water applied was determined from water retention curves for the soils. Pertinent soil water relations data to develop these curves are presented in Table 1,.., The Tifton loamy sand was composed of $80.4 \%$ sand, $9.0 \%$ salt, $7.0 \%$ clay, and $3.6 \%$ organic matter in the 0 - to $30-\mathrm{cm}$ profile. In the same profile depth, the Bonifay sand was composed of $92.1 \%$ sand, $2.0 \%$ silt, $4.1 \%$ clay, and $1.8 \%$ organic matter.

Climatological data, including maximum and minimum air temperatures, rainfall, open pan evaporation, wind movement, and relative humidity, were collected daily at the research site.

Plots were hand-tilled to incorporate fertilizers applied at rates of $60 \mathrm{~N}-52 \mathrm{P}-150 \mathrm{~K}$ (kg-hal). Transplants were set in two rows $90 \mathrm{~cm}$ apart with $30 \mathrm{~cm}$ between plants within the rows to give an equivalent plant density of 2700 plants/ha. Transplants were set 9 June 1982 and 20 June 1983. Weeds were controlled by hand, and other pest control was according to recommendations for Georgia (Granberry et al., 1986). Sweetpotato foliage was removed and roots were harvested by hand 13 Sept. 1982 and 26 Sept. 1983. Roots were graded as canner $(2.5$ to $5 \mathrm{~cm} \mathrm{di-}$ ameter; 5 to $18 \mathrm{~cm}$ length) U.S. \#1 (5 to $9 \mathrm{~cm}$ diameter; 8 to $23 \mathrm{~cm}$ length), jumbo (roots having diameter or length greater than U.S. \#1), and cull. The weight in each grade was determined.

Yield and water use data were subjected to analyses of variance using a split-plot design wherein soil type-crop season combinations were main plots and irrigation regimes were subplots. There were no significant soil type-crop season $\mathrm{x}$ irrigation regime interactions.

\section{Results and Discussion}

Water use was greater when sweetpotatoes were grown on a Tifton loamy sand than on a Bonifay sand both years (Table 2). Total and jumbo root yields were also greater when sweetpotatoes were grown on a Tifton loamy sand soil in 1983. Marketable yields were lower on Bonifay sand than on Tifton loamy sand in 1982 but not in 1983. The greatest yield of canner grade roots was produced on Bonifay sand in 1983. Although we did not measure foliage growth, we observed that foliage cover occurred more rapidly when sweetpotatoes were grown on Tifton loamy sand than on Bonifay sand both years.

Water use by sweetpotatoes irrigated during the entire grow-

Table 1. Available soil water content at various soil water tensions and profile depths in Tifton loamy sand and Bonifay sand sweetpotato lysimeter plots.

\begin{tabular}{cccccc}
\hline \hline \multirow{2}{*}{$\begin{array}{c}\text { Profile } \\
\text { depth }\end{array}$} & \multicolumn{5}{c}{ Soil water content $^{2}$} \\
\cline { 2 - 6 }$(\mathrm{cm})$ & 8 & \multicolumn{5}{c}{ Soil water tension $(\mathrm{kPa})$} \\
\cline { 2 - 6 } & \multicolumn{5}{c}{ Tifton loamy sand } \\
$0-15$ & 0.091 & 0.068 & 0.051 & 0.046 & 0.041 \\
$16-30$ & 0.091 & 0.068 & 0.051 & 0.046 & 0.041 \\
$31-45$ & 0.056 & 0.029 & 0.018 & 0.011 & 0.008 \\
$46-60$ & 0.119 & 0.084 & 0.074 & 0.064 & 0.054 \\
& \multicolumn{5}{c}{ Bonifay sand } \\
$0-15$ & 0.076 & 0.042 & 0.026 & 0.021 & 0.017 \\
$16-30$ & 0.076 & 0.042 & 0.026 & 0.021 & 0.017 \\
$34-45$ & 0.050 & 0.029 & 0.017 & 0.013 & 0.011 \\
$46-60$ & 0.050 & 0.029 & 0.017 & 0.013 & 0.011 \\
\hline
\end{tabular}

${ }^{2}$ Soil water content expressed as cubic millimeters of available water per cubic millimeters of soil.
Table 2. Effect of soil type and growing season on yield and water use by 'Georgia Jet' sweetpotato. '

\begin{tabular}{|c|c|c|c|c|c|c|}
\hline \multirow[b]{2}{*}{ Soil-season } & \multirow{2}{*}{$\begin{array}{c}\text { Water } \\
\text { applied } \\
(\mathrm{mm})\end{array}$} & \multicolumn{5}{|c|}{ Yield $\left(\mathrm{mg} \cdot \mathrm{ha}^{-1}\right)^{y}$} \\
\hline & & Total & Marketäble & U.S. \#1 & Jumbo & Canner \\
\hline Tifton-1982 & $263 \mathrm{~b}$ & $45.8 \mathrm{bc}$ & $44.2 \mathrm{a}$ & $33.4 \mathrm{a}$ & $1.2 \mathrm{~b}$ & $9.6 \mathrm{~b}$ \\
\hline 1983 & $285 \mathrm{a}$ & 58.5 a & $46.3 \mathrm{a}$ & $33.3 \mathrm{a}$ & $3.2 \mathrm{a}$ & 9.9 \\
\hline Bonifay-1982 & $203 c$ & $42.5 \mathrm{c}$ & $38.1 \mathrm{~b}$ & $26.6 \mathrm{~b}$ & $0.5 \mathrm{~b}$ & $11.0 \mathrm{~b}$ \\
\hline 1983 & $209 \mathrm{c}$ & $48.8 \mathrm{~b}$ & $41.2 \mathrm{ab}$ & $20.8 \mathrm{c}$ & $0.5 \mathrm{~b}$ & $19.9 \mathrm{a}$ \\
\hline
\end{tabular}

${ }^{2}$ Data are averages of six irrigation treatments and four replications.

'Mean separation, within columns, by Duncan's multiple range test, $P$ $=0.05$.

Table 3. Effect of irrigation regime on yield and water use by 'Georgia Jet' sweetpotato.'

\begin{tabular}{lcccccc}
\hline \hline \multirow{2}{*}{$\begin{array}{l}\text { Irrigation } \\
\text { regime } \\
(\mathrm{kPa})\end{array}$} & $\begin{array}{c}\text { Water } \\
\text { applied }\end{array}$ & \multicolumn{5}{c}{ Yield $\left(\mathrm{mg} \cdot \mathrm{ha}^{-\mathrm{t}}\right)^{\mathrm{y}}$} \\
\cline { 4 - 8 } & $(\mathrm{mm})$ & Total & Marketable & U.S. \#1 & Jumbo & Canner \\
\hline 25 & $281 \mathrm{a}$ & $53.7 \mathrm{a}$ & $47.4 \mathrm{a}$ & $33.5 \mathrm{a}$ & $1.3 \mathrm{a}$ & $12.6 \mathrm{a}$ \\
50 & $247 \mathrm{~b}$ & $47.7 \mathrm{a}$ & $41.7 \mathrm{ab}$ & $26.8 \mathrm{~b}$ & $0.8 \mathrm{a}$ & $14.1 \mathrm{a}$ \\
100 & $195 \mathrm{~d}$ & $41.0 \mathrm{~b}$ & $35.1 \mathrm{~b}$ & $24.3 \mathrm{~b}$ & $0.4 \mathrm{a}$ & $10.3 \mathrm{a}$ \\
$100-25^{\mathrm{x}}$ & $227 \mathrm{c}$ & $47.6 \mathrm{a}$ & $41.3 \mathrm{ab}$ & $27.0 \mathrm{~b}$ & $1.3 \mathrm{a}$ & $12.9 \mathrm{a}$ \\
$25-100^{\mathrm{x}}$ & $247 \mathrm{~b}$ & $51.5 \mathrm{a}$ & $45.3 \mathrm{a}$ & $29.8 \mathrm{ab}$ & $2.0 \mathrm{a}$ & $13.5 \mathrm{a}$ \\
$25-100-25^{\mathrm{w}}$ & $244 \mathrm{~b}$ & $52.0 \mathrm{a}$ & $44.3 \mathrm{a}$ & $29.4 \mathrm{ab}$ & $2.3 \mathrm{a}$ & $12.5 \mathrm{a}$ \\
\hline
\end{tabular}

${ }^{2}$ Data are averages of four soil-season combinations and four replications.

'Mean separation, within columns, by Duncan's multiple range test, $P$ $=0.05$.

xoil water tensions at which irrigation was applied before and after initiation of root enlargement.

wPlots irrigated at a soil water tension of $100 \mathrm{kPa}$ from initiation of root enlargement until a mean root diameter of 4 to $5 \mathrm{~cm}$.

ing season at soil water tensions of 50 or $100 \mathrm{kPa}$ were $88 \%$ and $69 \%$ as great as the water use by sweetpotatoes irrigated at $25 \mathrm{kPa}$ soil water tension (Table 3 ). Water use was also reduced by exposure of the sweetpotatoes to a $100-\mathrm{kPa}$ water stress before or during storage root development. These results contradict those of Jones (1961) who reported similar water use rates when sweetpotatoes were irrigated at $20 \%, 40 \%, 60 \%$, and $80 \%$ available soil water. The field bins used by Jones extended only $30 \mathrm{~cm}$ below the surface and were not equipped with a drainage system that would effectively isolate plots from each other or from groundwater intrusion. The lysimeter system used for our study provided protection from both rainfall and groundwater intrusion. Lateral water movement from rainfall or irrigation commonly occurs in soils having dramatically different permeability rates in topsoil and subsoil profiles (Bruce et al., 1980).

Irrigation regimes influenced sweetpotato yields (Table 3). Yield of U.S. \#1 grade sweetpotatoes was highest when plots were irrigated at $25 \mathrm{kPa}$ soil water tension throughout their growth. However, yields of U.S. \#1 roots were not significantly reduced as long as plants were irrigated at $25 \mathrm{kPa}$ before root enlargement, even when subsequently irrigated at $100 \mathrm{kPa}$ during early root enlargement or throughout root enlargement. Jumbo and canner yields were not affected by irrigation regime. Total and marketable yields were reduced only when sweetpotatoes were irrigated at $100 \mathrm{kPa}$ throughout their growth. These results substantiate reports by Lambeth (1956) and Lana and Peterson (1956) that sweetpotato yields respond to irrigation applications at $>20 \%$ to $25 \%$ available soil water.

Correlation analyses showed significant $(\mathrm{P}=0.01)$ positive relationships between water use and total yield $(r=0.52)$, 
Table 4. Water use (ET), pan evaporation $\left(\mathrm{E}_{\mathrm{p}}\right)$, and crop factors $\left(\mathrm{CF}=\mathrm{ET} / \mathrm{E}_{\mathrm{p}}\right)$ for sweetpotato irrigated at 25,50 , and $100 \mathrm{kPa}$ as functions of days from transplanting $(\mathrm{D})^{2}{ }^{2}$

\begin{tabular}{|c|c|c|}
\hline \multicolumn{2}{|c|}{$\begin{array}{l}\text { Irrigation Equations for computing cumulative and daily pan evaporation } \\
\text { (kPa) and water use and daily crop factor values }\end{array}$} & $R^{2}$ \\
\hline $\begin{array}{r}25 \\
50 \\
100\end{array}$ & 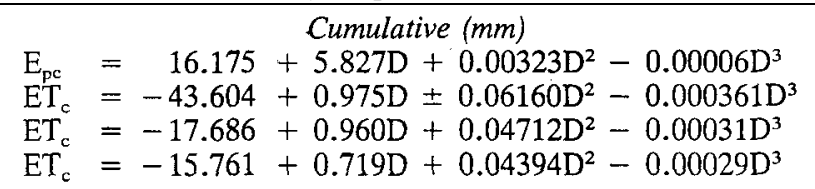 & $\begin{array}{l}0.996 \\
0.987 \\
0.884 \\
0.935\end{array}$ \\
\hline $\begin{array}{r}25 \\
50 \\
100\end{array}$ & $\begin{array}{l}\text { Daily }(\mathrm{mm}) \\
\mathrm{E}_{\mathrm{p}}=5.827+0.0064 \mathrm{D}-0.00018 \mathrm{D}^{2} \\
\mathrm{ET}=0.975+0.1239 \mathrm{D}-0.00109 \mathrm{D}^{2} \\
\mathrm{ET}=0.960+0.0943 \mathrm{D}-0.00092 \mathrm{D}^{2} \\
\mathrm{ET}=0.719+0.0879 \mathrm{D}-0.00085 \mathrm{D}^{2}\end{array}$ & \\
\hline $\begin{array}{r}25 \\
50 \\
100 \\
\end{array}$ & $\begin{array}{l}E T / E_{p} \\
\mathrm{CF}_{25}=0.120+0.023 \mathrm{D}-0.00019 \mathrm{D}^{2} \\
\mathrm{CF}_{50}=0.103+0.019 \mathrm{D}-0.00018 \mathrm{D}^{2} \\
\mathrm{CF}_{100}=0.074+0.018 \mathrm{D}-0.00017 \mathrm{D}^{2}\end{array}$ & \\
\hline
\end{tabular}

Maximum days from transplanting $=98$ days.

marketable yield ( $r=0.47)$, U.S. \#1 yield ( $r=0.53)$ and jumbo yield $(r=0.37)$. The relationship between water use and canner yield $(r=-0.22)$ was also significant $(P=0.01)$.

Water applied should be a valid estimate of evapotranspiration or water use since these plots were protected from rainfall and groundwater intrusions and water additions were based on water contents at various depths in the soil profiles. Cumulative pan evaporation $\left(\mathrm{E}_{\mathrm{pc}}\right)$ and cumulative water use (ET) for sweetpotatoes irrigated at 25,50 , and $100 \mathrm{kPa}$ throughout growth were compiled for each crop. The relationship of $\mathrm{E}_{\mathrm{pc}}$ and $\mathrm{ET}$ to plant age (days from transplanting) for the combined data of the four crops was established by regression analyses using the general linear models procedure of SAS (Ray, 1982). Equations to describe these relationships are shown in Table 4. Sufficient wafer $(25$ to $40 \mathrm{~mm})$ was applied during the 1 st week after transplanting to assure that the soil profile was recharged. These water applications were not included in the computation of evapotranspiration, since the amount of water applied at the last irrigation would also recharge the soil profile.

The equations accounted for $99.6 \%$ of the variation in $E_{p c}$ and $88.4 \%$ to $98.7 \%$ of the variation in $\mathrm{ET}_{\mathrm{c}}$ of sweetpotatoes irrigated at 25, 50, and $100 \mathrm{kPa}$. Daily pan evaporation $\left(\mathrm{E}_{\mathrm{p}}\right)$ and evapotranspiration (ET) equations, computed as the derivative of the $E_{p c}$ and $E_{c}$ equations, show that both $E_{p}$ and $E T$ initially increased, and then decreased with age of the sweetpotato crop. The quadratic water use response with age by sweetpotato is in agreement with the results of Jones (1961) and Lambeth (1956).

Since both $\mathrm{E}_{\mathrm{p}}$ and ET changed quadratically with age, arrays of $E_{p}$ and ET changes with age were computed from these equations. Crop water use coefficient or crop factor (CF) values (Stansell Smittle, 1989) expressed as the ratio of ET : $\mathrm{E}_{\mathrm{p}}$ were computed from the ET and $\mathrm{E}_{\mathrm{p}}$ arrays throughout growth of the crop. Regression equations to describe the relationships of crop factor values to sweetpotato age are also presented (Table 4). These equations show that crop factor values for sweetpotatoes initially increase and then decrease with age, as also reported by Jones (1961); however, the equations refine earlier research by providing a daily adjustment for $\mathrm{E}_{\mathrm{p}}$ that allows $\mathrm{E}_{\mathrm{p}}$ to be used in the development of irrigation scheduling models (Smittle et al., 1990).
We have shown that yield of U.S. \#1 sweetpotatoes was greatest with irrigation applications when the soil water tension at $23 \mathrm{~cm}$ reached $25 \mathrm{kPa}$. This irrigation regime also required more water than did irrigation at 50 and $100 \mathrm{kPa}$ throughout growth or when a 100-kPa water stress occurred before or after initiation of storage root development.

\section{Literature Cited}

Bowers, J. L., R.H. Benedict, and J. McFerran. 1956. Irrigation of sweet potatoes, snap beans and cucumber in Arkansas. Ark. Agr. Expt. Sta. Bul. 578.

Bruce, R. R., J.L. Chesness, T.C. Keisling, J.E. Pallas, Jr., D.A. Smittle, J.R Stansell, and A.W. Thomas. 1980. Irrigation of crops in the southeastern United States: Principles and practices. U.S. Dept. Agr./Sci. Ed, Admin. Agr. Rev. \& Man. ARM-S-9.

Chua, L.K. and S.J. Kays. 1981. Effect of soil oxygen concentration on sweet potato storage root induction and/or development. J. Hort. Sci. 16:71-73.

Ghuman, B.S. and R. Lal. 1983. Mulch and irrigation effects on plant-water relations and performance of cassava and sweet potato. Field Crops Res. 7:13-29.

Granberry, D. M., P. Colditz, and W.J. McLaurin. 1986. Sweet potato. Ga. Ext. Bid. 677.

Hammett, H. L., R.J. Constantin, and T.P. Hernandez. 1982. The effect of phosphorus and soil moisture levels on yield and processing quality of 'Centennial' sweet potatoes. J. Amer. Soc. Hort. Sci. 107:119-122.

Hernandez, T. P., J.C. Miller, and L.G. Jones. 1965. The value of irrigation in sweet potato production in Louisiana. La. Agr. Expt. Sta. Bul. 607.

Jones, S.T. 1961. Effects of irrigation at different levels of soil moisture on yield and evapotranspiration rate of sweet potatoes. Proc. Amer. Soc. Hort. Sci. $77: 458-462$.

Lambeth, V.N. 1956. Studies in moisture relationships and irrigation of vegetables. Mo. Agr. Expt. Sta. Res. Bul. 605.

Lana, E.P. and L.E. Peterson. 1956. The effect of fertilizer-irrigation combinations on sweet potatoes in Buckner coarse sand. Proc. Amer. Soc. Hort. Sci. 68:400-405.

Penman, H. L., D.E. Angus, and C.H.M. Van Bavel. 1967. Microclimate factors affecting evaporation and transpiration, p. 483-505. In: R.M. Hagan, H.R. Haise, and T.W. Edminster (eds.). Irrigation of agricultural lands. Amer. Sot. Agron. Madison, Wis.

Ray, A.A. 1982. SAS user's guide: Statistics. 1982 ed. SAS Institute. Inc., Cary, N.C.

Smittle, D. A., W.L. Dickens, and J.R. Stansell. 1990. An irrigation scheduling model for snap beans. J. Amer. Soc. Hort. Sci. 115:226-230.

Stansell, J.R. and D.A. Smittle. 1980. Effects of irrigation regimes on yield and water use of snap beans (Phaseolus vulgaris L.) J. Amer. Soc. Hort. Sci. $105: 869-873$

Stansell, J.R. and D.A. Smittle. 1989. Effects of irrigation regimes on yield and water use of summer squash. J. Amer. Soc. Hort. Sci. 114:196-199. 